\title{
Latent pigments activated by heat
}

$\mathrm{O}$ rganic pigments are used as colourants in paints, plastics, printing inks ${ }^{1}$ and in the electronics industries ${ }^{2}$. They can be distinguished from dyes in that they are insoluble. Whereas dyes readily dissolve to give homogeneous coloration, the application of organic pigments frequently requires a time- and energy-consuming dispersion step. Here we report a method for converting a pigment into a suitable precursor, a 'latent' pigment. Like a dye, the latent pigment is readily soluble or homogeneously dispersible in the application medium, and on subsequent thermal treatment it can be transformed in situ to the parent pigment.

The insolubility of organic pigments in the majority of solvents or matrices is due either to the existence of strong intermolecular $\pi-\pi$ interactions in planar, closely packed systems (for example, the phthalocyanines), or to other strong intermolecular interactions, most commonly hydrogen bonding as in 3,6-diphenyl-1,4-diketopyrrolo[3,4-c] pyrrole $^{3,4}$ (DPP; Fig. 1a). We have created ${ }^{5}$ latent pigments whose hydrogen bonding is transiently disrupted by the addition of protective groups. We use a protective group such as the $t$-butoxycarbonyl radical, because it breaks down the hydrogen-bonded pigment network to yield soluble derivatives and is easily removed by thermal treatment ${ }^{6}$.

Using DPP (compound 1), a wellknown commercial red pigment, as a model compound, we succeeded in converting the pigment into $N, N^{\prime}$-bis-( $t$-butoxycarbonyl)3,6-diphenyl-1,4-diketo-pyrrolo[3,4-c]pyr-
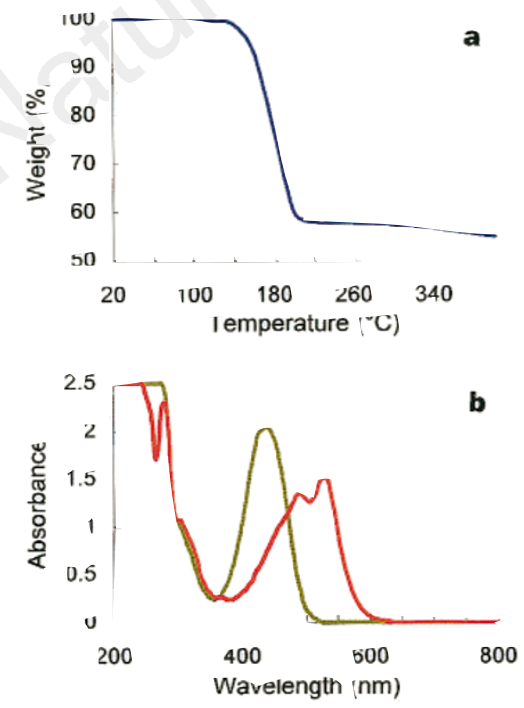

a
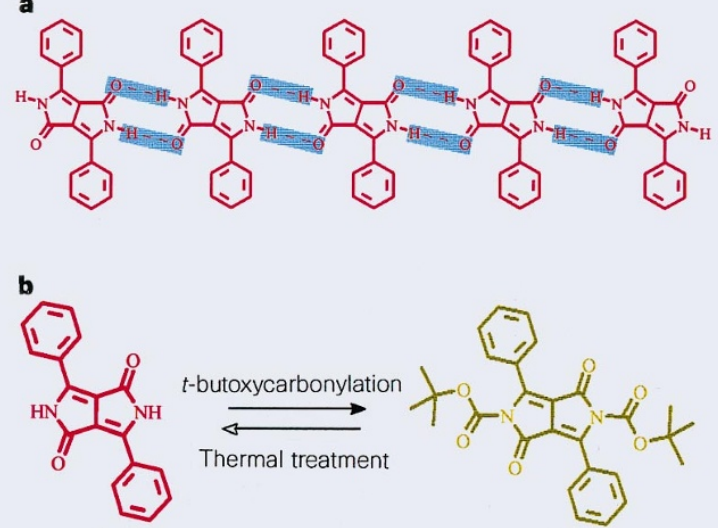

1
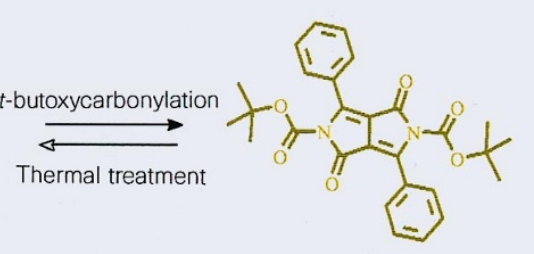

2

Figure 1a, Schematic illustration of the hydrogen-bonding network of DPP. $\mathbf{b}$, Insoluble parent pigment (1) and soluble latent pigment (2).

role (2) in high yield under remarkably mild conditions, by simply stirring the pigment in tetrahydrofuran (THF) at room temperature with two equivalents of di- $(t-$ butyl)-dicarbonate, using $N, N^{\prime}$-dimethylaminopyridine as a catalyst ${ }^{5,7}$ (Fig. 1b). The carbamate formation in 2 is accompanied by a large hypsochromic shift of the maximum absorption in the solid state from 540 $\mathrm{nm}$ (ref. 4) to $439 \mathrm{~nm}$.

The solubility of the latent pigment surpasses by several orders of magnitude the solubility of the parent pigment in common organic solvents. It has a solubility of 36 g per litre in xylene and 120 g per litre in cyclopentanone at room temperature, whereas 1 is practically insoluble $\left(<10^{-3} \mathrm{~g}\right.$ per litre). Moreover, compound 2 undergoes simultaneous thermal elimination of both protective groups at about $180{ }^{\circ} \mathrm{C}$ (Fig. 2a) to afford the parent pigment in high purity and quantitative yield, with $\mathrm{CO}_{2}$ and isobutene as gaseous products of the elimi-

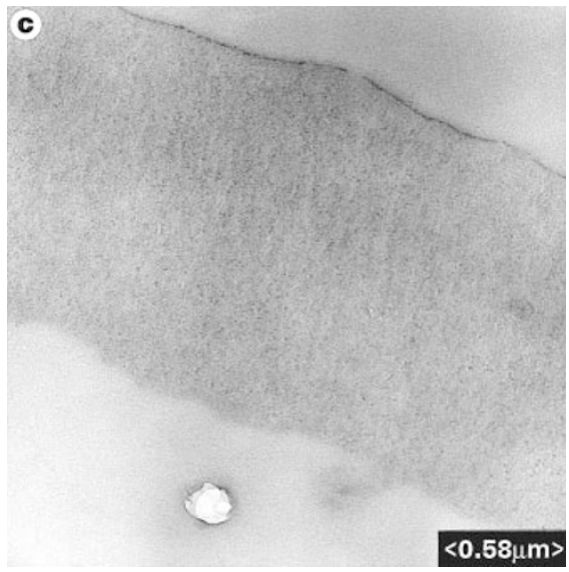

Figure 2a, Weight loss of $N_{,} N^{\prime}$-bis-(t-butoxycarbonyl)-DPP as a function of temperature (rate, $10{ }^{\circ} \mathrm{C} \mathrm{min}{ }^{-1}$; onset, $163.6^{\circ} \mathrm{C}$; midpoint, $177.7^{\circ} \mathrm{C}$; end point $191.8^{\circ} \mathrm{C}$; step height, $\left.40.7 \%\right)$. b, Ultraviolet-visible absorption spectra of a 1.5- $\mu$ m-thick p-hydroxy-polystyrene film containing $40 \% N, N^{\prime}$-bis-(t-butoxycarbonyl)-DPP, spin-coated (yellow) and after 2 min at $180{ }^{\circ} \mathrm{C}$ (red). c, Transmission electron micrograph of an ultramicrotome-cut cross-section of a 1.5- $\mu \mathrm{m}$-thick p-hydroxy-polystyrene film containing $40 \% N_{,} N^{\prime}$-bis-(t-butoxycarbonyl)-DPP, after 2 min treatment at $180^{\circ} \mathrm{C}$.

nation. Analytical data and powder X-ray diffraction diagrams of DPP formed by the thermal decomposition of the soluble precursor are identical to those of DPP prepared by standard synthetic procedures ${ }^{3}$.

We prepared thin, yellow films $(\sim 1.5$ $\mu \mathrm{m})$ of $p$-hydroxy-polystyrene containing roughly $40 \%$ of the latent pigment by spincoating a cyclopentanone solution of both components on quartz substrates. Thermal treatment for $2 \mathrm{~min}$ at $180{ }^{\circ} \mathrm{C}$ resulted in the in situ regeneration of the parent pigment, as evidenced by optical spectroscopy (Fig. 2b), providing highly transparent red films. Further thermal treatment at $180^{\circ} \mathrm{C}$ or higher temperatures (up to $220^{\circ} \mathrm{C}$ ) produced no change in the absorption spectrum. The optical spectrum of DPP formed by this process has a profile identical to that of a DPP thin film from vapour deposition ${ }^{4}$. Transmission electron micrographs of these thin films show the homogeneous distribution of the freshly formed pigment particles $(<20 \mathrm{~nm})$ throughout the whole matrix (Fig. 2c).

Our method combines the advantages of dye-like solubility with the solid-state properties of insoluble pigments ${ }^{1}$, and could have significant advantages for pigment technology because it simplifies the application process but still allows homogeneous distribution of pigment nanoparticles in a substrate $^{8}$. Our technique is applicable to most commercial high-performance organic pigments bearing functional groups ${ }^{9}$ capable of reacting with standard protective group reagents. In addition, our approach might become a powerful tool for probing and even influencing the role of hydrogen bonding in crystal engineering and molecular recognition ${ }^{10}$.

J. S. Zambounis, Z. Hao, A. Iqbal

Pigments Division, Ciba Specialty Chemicals Inc., CH-4002 Basel, Switzerland

e-mail:john_s.zambounis@chbs.mhs.ciba.com 
1. Herbst, W. \& Hunger, K. Industrial Organic Pigments (VCH, Weinheim, 1993).

2. Gregory, P. High-Technology Applications of Organic Colorants (Plenum, New York, 1991).

3. Iqbal, A. et al. Bull. Soc. Chim. Belg. 97, 615-643 (1988).

4. Mizuguchi, J. \& Rihs, G. Ber. Bunsenges. Phys. Chem. 96, 597-606 (1992).

5. Zambounis, J. S., Hao, Z. \& Iqbal, A. US Patent No. 5,484,943 (1996)

6. Rawal, V. H. \& Cava, M. P. Tetrahedr. Lett. 26, 6141-6142 (1985).

7. Grehn, L. \& Ragnarsson, U. Angew. Chem. Int. Edn Engl. 23, 296-301 (1984).

8. Schädeli, U., Zambounis, J. S., Hao, Z., Iqbal, A. \& Dubas, H. European Patent Application No. 0654711 Al (1996).

9. Hao, Z., Zambounis, J. S. \& Iqbal, A. US Patent No. 5,561,232 (1996).

10. Lehn, J.-M. Angew. Chem. Int. Edn Engl. 29, 1304-1319 (1990).

\section{Photosynthesis or} planktonic respiration?

The nutrient-poor (oligotrophic) regions of the open ocean cover $30 \%$ of the Earth's surface. Microscopic plants (phytoplankton) living in this habitat account for about $10 \%$ of global $\mathrm{CO}_{2}$ fixation ${ }^{1}$. Most of this organic production is rapidly respired within a microbial food web dominated by photosynthetic bacteria, heterotrophic bacteria and small $(<5 \mu \mathrm{m}$ diameter) protozoa and algae, with a small amount (about $1 \%$ of global $\mathrm{CO}_{2}$ fixation) being exported from nutrient-poor upper ocean regions to the interior of the ocean ${ }^{2,3}$. Thus, on average, photosynthesis exceeds respiration in the sunlit 'euphotic' zone of the oligotrophic ocean. This view appears to have been challenged by del Giorgio and co-workers ${ }^{4}$.

Although their conclusion that "...bacterial respiration is generally high, and tends to exceed phytoplankton net production in unproductive systems (less than 70 to $120 \mu \mathrm{g}$ carbon per litre per day)" is likely to be valid for lakes, it is unlikely to hold in the oligotrophic ocean. An excess of net photosynthesis over respiration is evident in seasonal accumulation of $\mathrm{O}_{2}$ in near-surface waters ${ }^{5}$ at those times when nutrient supply from the interior of the ocean is cut off by vertical stratification. Net photosynthesis is also evident in downward transport (export) of particulate ${ }^{2}$ and dissolved organic matter ${ }^{3}$ from the euphotic zone to the interior of the ocean.

The conclusion of del Giorgio et al. that the oligotrophic ocean euphotic zone is net heterotrophic was based on analysis of estimates of bacterial respiration and primary production taken from the literature. But a systematic bias in methodology, possibly the consideration of phytoplankton respiration, may account for such a discrepancy.

Both bacterial biomass and bacterial respiration in oligotrophic ocean environments was probably overestimated by del Giorgio et al. Photosynthetic picoplankton can be mistaken for heterotrophic bacteria in conventional epifluorescence counts, leading to an overestimate of the abundance of heterotrophic bacteria in the most oligotrophic waters. For example, photosynthetic bacteria within the genus Prochlorococcus accounted for $31 \%$ of total bacterial counts (upper $200 \mathrm{~m}$ ) in the oligotrophic North Pacific, and the biomass of photosynthetic picoplankton exceeds that of heterotrophic bacteria ${ }^{6}$.

del Giorgio et al. relied on dark $\mathrm{O}_{2}$ consumption in the $<0.8-2-\mu \mathrm{m}$ size fraction to estimate bacterial respiration. But in fact phytoplankton are likely to contribute significantly to dark oxygen consumption in this size fraction. Respiration is strongly correlated with growth rate in phytoplankton. For phytoplankton with a specific growth rate of $0.7 \mathrm{~d}^{-1}$ typical of open ocean $^{7}$, a specific respiration of $0.4 \mathrm{~d}^{-1}$ is anticipated $^{8}$. This estimate of phytoplankton respiration can be compared with a calculation of the specific bacterial respiration rate of $0.4 \mathrm{~d}^{-1}$ based on a growth rate of $0.1 \mathrm{~d}^{-1}$ and growth efficiency of 0.2 . Given equal biomass of heterotrophic bacteria and picophytoplankton ${ }^{6}$, it is likely that picophytoplankton account for about $50 \%$ of oxygen consumption in the $<0.8-2-\mu \mathrm{m}$ size fraction of oligotrophic ocean waters. As a consequence, heterotrophic bacterial respiration may have been overestimated by $200 \%$ in such waters. del Giorgio et al. compared their estimate of "bacterial" respiration with net photosynthesis. As the contribution of phytoplankton to respiration is already included in the net photosynthesis measurement ${ }^{10}$, del Giorgio et al. could have counted the contribution of picophytoplankton to respiration twice in their analysis.

In their paper, del Giorgio et al. assumed a respiratory quotient (RQ) of $1.0 \mathrm{CO}_{2}$ evolved per $\mathrm{O}_{2}$ consumed to convert bacterial respiration from oxygen to carbon equivalents. This RQ is unconstrained by observations for open ocean bacteria, but it is likely to be an overestimate of $\mathrm{CO}_{2}$ evolution from respiration of organic matter that includes proteins and lipids in addition to carbohydrates. Oceanographers typically use a photosynthetic quotient of $1.25 \mathrm{O}_{2}$ evolved per $\mathrm{CO}_{2}$ assimilated to convert measurements of primary production from carbon to oxygen equivalents ${ }^{11}$ for comparison with respiration rates measured as $\mathrm{O}_{2}$ consumption. Multiplying the $200 \%$ overestimate of heterotrophic bacterial respiration by a photosynthetic quotient of 1.25 leads to an error of $250 \%$.

Cross-system analyses, such as that undertaken by del Giorgio and co-workers, are necessary for clarifying our understanding of the relationship between heterotrophic and photosynthetic metabolism in aquatic systems. However, the conclusion of net heterotrophy of unproductive oceanic systems needs to be tempered, given uncer- tainty in phytoplankton respiration rates or other possible systematic errors in bacterial respiration and primary productivity measurements.

\section{Richard J. Geider}

Marine Biological Association of

the United Kingdom,

The Laboratory, Citadel Hill,

Plymouth PL1 2PB, UK

e-mail: rdg@wpo.nerc.ac.uk

1. Behrenfeld, M. J. \& Falkowski, P. G. Limnol. Oceanogr. 42, 1-20 (1997).

2. Michaels, A. F., Bates, N. R., Buesselere, K. O., Carlson, C. A. \& Knap, A. H. Nature 372, 537-540 (1994).

3. Carlson, C. A., Ducklow, H. W. \& Michaels, M. F. Nature 371, 405-408 (1994).

4. del Giorgio, P. A., Cole, J. J. \& Cimbleris, A. Nature 385 148-151 (1997).

5. Spitzer, W. S. \& Jenkins, W. J. J. Mar. Res. 47, 169-196 (1989).

6. Campbell, L., Nolla, H. A. \& Vaulot, D. Limnol. Oceanogr. 39, 954-961 (1994)

7. Laws, E. A., Ditullio, G. R., Carder, K. L., Betzer, P. R. \& Hawes, S. Deep-Sea Res. 37, 715-730 (1990).

8. Geider, R. J. in Primary Productivity and Biogeochemical Cycles in the Sea (eds Falkowski, P. G. \& Woodhead, A. D.) 333-360 (Plenum, New York, 1992).

9. Fuhrman, J. A., Sleeter, T. D., Carlson, C. A. \& Proctor, L. M Mar. Ecol. Prog. Ser. 57, 207-217 (1989).

10. Williams, P. J. LeB. et al. J. Plankton Res. 18, 1961-1974 (1986). 11. Grande, K. D. et al. Deep-Sea Res. 36, 1621-1634 (1989).

del Giorgio and Cole reply - Geider raises two main issues: first, he points to substantial evidence suggesting net autotrophy in surface ocean waters; and second, he argues that the estimates of bacterial respiration we used in our paper ${ }^{1}$, which are based largely on measurements of oxygen consumption in size-fractionated samples, could overestimate the contribution of bacteria.

The surface waters of the ocean, taken as a whole, are probably net autotrophic, for the reasons Geider states as well as others. We were careful to state our conclusions about open ocean systems to reflect this view. In fact, we suggested several mechanisms, including temporal lags and export of detrital organic carbon from more productive marine areas, that would be consistent with both our analysis and the idea of oceanic surface waters being net autotrophic. Thus, we do not disagree with Geider about the net autotrophy in oceanic surface waters.

The second issue raised by Geider is whether the estimates of respiration are representative of the metabolic rates of heterotrophic bacteria in the open seas. Geider argues that they are not, because of the possible contribution of minute autotrophs to the small-size planktonic fraction. From the point of view of the organic carbon balance, it does not matter if some of the respiration is due to the contribution of autotrophs. If one accepts the rate measurements, the destruction of organic matter by respiration is still larger than the production by photosynthesis. Geider estimates autotrophic and heterotrophic picoplankton respiration based on typical growth and specific respiration rates of these organisms in the sea. As part of this calculation, he 